\title{
A Taphonomic Study of Crocodylus porosus (Crocodylidae) and Tomistoma schlegelii (Gavialidae) Remains from Western Sarawak, Malaysian Borneo: Applications for Public Education
}

\author{
RUHANA HASSAN*1, NUR FATIMAH MOHD AZIZI ${ }^{1}$, MUHAMMAD AMIRUL ARIB MD \\ ADZHAR $^{1}$, MOHD IZWAN ZULAINI ABDUL GANI ${ }^{1}$, RAMBLI AHMAD ${ }^{2}$ \& CHARLES LEH \\ MOI UNG ${ }^{3}$
}

${ }^{1}$ Faculty of Resource Science and Technology, Universiti Malaysia Sarawak, 94300 Kota Samarahan, Sarawak, Malaysia; ${ }^{2}$ Sarawak Forestry Corporation, Lot 218, KCLD, Jalan Tapang, Kota Sentosa, 93250 Kuching, Sarawak, Malaysia; ${ }^{3}$ The Sarawak Museum, Barrack Road, 93000 Kuching, Sarawak, Malaysia

*Corresponding authors: hruhana@ unimas.my

\begin{abstract}
This study documented details of the dentitions, skulls and other skeletal remains of Crocodylus porosus and Tomistoma schlegelii, from western part of Sarawak, Malaysian Borneo. The remains of both reptiles were exhumed, followed by standard cleaning procedures and then detail morphological assessments were carried out accordingly. Both species show similar structure of vertebral columns, but $T$. schlegelii has the following unique structures: a long and narrower snout, D-shaped eye sockets, long and sharp pointed protruding quadratojugal bones, straight maxillae and dentary, a smooth surfaced skull, elongated triangular suborbital fenestrae, round shaped internal nares and visible supraoccipital from a dorsal view. C. porosus has heterodont dentition with bluntpointed and irregular size of teeth whereas T. schlegelii has almost homodont dentition with sharp and similar size teeth. This is the first collection of teeth, skulls and other skeletal remains of both species obtained from Sarawak, and the materials have been used regularly to educate the public through science exhibitions, hoping they will spark the interests of young budding scientists to be involved in wildlife taphonomic studies in the future.
\end{abstract}

Keywords: Crocodylus porosus, dentition, reptile, skeletal remain, Tomistoma schlegelii

Copyright: This is an open access article distributed under the terms of the CC-BY-NC-SA (Creative Commons Attribution-NonCommercialShareAlike 4.0 International License) which permits unrestricted use, distribution, and reproduction in any medium, for non-commercial purposes, provided the original work of the author(s) is properly cited.

\section{INTRODUCTION}

The saltwater crocodile, Crocodylus porosus has a wide distribution, ranging from Australia, Bangladesh, Brunei, Mynmar, Timor Leste (East Timor), India (including Andaman and Nicobar Islands), Indonesia, Malaysia, Palau, Papua New Guinea (including Bismark archipelago and other island chains), the Philippines, Sri Lanka and Solomon Islands (Britton, 2012). C. porosus (locally name: "Buaya Katak" or "Buaya Air Masin") and Tomistoma schlegelii (local name: "Buaya Jejulung") are found in Sarawak (Hassan et al., 2016; Stuebing, Bezuijen, Auliya \& Voris, 2006). Previously, both C. porosus and $T$. schlegelii were in the same family namely Family Crocodylidae but later evidence from nuclear gene inferences had placed T. schlegelii into Family Gavialidae (Willis, McAliley, Neely, \& Densmore, 2007). In Sarawak, the existence of T. schlegelii is less known compared to C. porosus, probably due to the secretive nature of the latter species (Hassan et al., 2016). The distribution of T. schlegelii is limited to the lowland regions of western Sumatra, Kalimantan and western Java (Indonesia), Sarawak and Peninsular Malaysia. T. schlegelii is classified in Appendix I of the Convention on International Trade of Endangered Species of Wild Fauna and Flora (CITES) (Bezuijen, Shwedick, Sommerlad, Stevenson \& Stuebing, 2010; Webb, Manolis \& Brien, 2010). For C. porosus in Sarawak, various conservation efforts, including strict law enforcement, had been successful, leading to the increased in populations over the 30-years period as reflected in the state crocodile surveys involving all 21 river basins (Zaini, Ripot, Ubang, Francis \& Simon, 2014). In 2016, Sarawak has been successful in transferring $C$. porosus from Appendix I to Appendix II of CITES, providing opportunity for sustainable management of the wild resource for the benefit of local people. The documentation on the density and ecology of C. porosus in Sarawak had been carried out by Bezuijen et al. (2010), Cox and Gombek (1985), Gani (2014), Gani and Hassan (2013), Hassan and Gani (2013), Hassan, Adzhar, Gani and Ahmad (2018) as well as Zaini et al. (2014). Research on T. schlegelii in Sarawak could be referred to Bezuijen, Shwedick, Simpson and Stuebing (2014), Cox and Gombek (1985), Hassan et al. (2016), Md Adzhar and Hassan (2017), Pine (2013), Stuebing, Sah, Lading and Jong (2003) and Stuebing et al. (2006). 
It is relatively easy to identify living crocodiles in the wild based on their morphological features, but it is a huge challenge when it comes to skeletal remains. Since both of the species are present in Sarawak, it is very likely to encounter their skeletonized elements. Ferraro and Binetti (2014) and Ritchie and Jong (2002) suggested that misattribution incidents related to skeletal remains identification often occur due to the lack reference guidelines. For instance, Ritchie and Jong (2002) claimed that there could be a misattribution incident involving discovery of a skull belonging to $C$. raninus, the long-forgotten species in Tasek Merembun, Brunei.

Gunther (1861) and Grigg and Gans (1993) had properly documented the details of head morphology and the dentition of $C$. porosus. In their study, Grigg and Gans (1993) involved specimens from Australia, while Gunther (1861) focused on crocodiles in the coastal region of India. For T. schlegelii, Bezuijen, Cannucciari, Ramono and Webb (1995) had produced description on the dentition and head morphology based on live specimens.

Since there is not yet any available documentation on skeletal remains (and teeth) of specimens from Sarawak, this study aimed to document and compare the structures of the skull, teeth and other bones from deceased $C$. porosus and T. schlegelii, hoping that the comprehensive descriptions will help in future wildlife taphonomic studies.

\section{MATERIALS \& METHODS}

\section{Excavation, General Cleaning and Storage}

The excavation of the animals' remains was conducted at Matang Wildlife Centre, Kuching, Sarawak on $18^{\text {th }}$ October 2016, with permission from Sarawak Forestry Corporation (SFC). The soil was exhumed, revealing two skeletal remains; one was identified as C. porosus and another as T. schlegelii. Dirt and soil were carefully removed from the remains using brushes and small spades. Pictures of the skeletal remains were captured by using a digital camera, SONY $\alpha 5000$. Each specimen was divided into four sections based on the estimation of the following segments:
i) section $\mathrm{A}$
: skull to cervical vertebrae
ii) section $\mathrm{B}$
: thoracic vertebrae
iii) section $\mathrm{C}$
: sacral vertebrae to half of caudal vertebrae
iv) section $\mathrm{D}$
: remaining caudal vertebrae until the tip of tail (if present).

The skeletal remains were removed following this order: cleaned with running water, stored in labelled plastic bags and transported immediately to Faculty of Resource Science and Technology, Universiti Malaysia Sarawak (UNIMAS). Bone cleansing was carried out manually. A toothbrush and running tap water were used to remove dirt and leftover tissues following the methodology of Shaker and El-Bably (2015). Bleaching steps involved soaking the bones in detergent solution for three days, to remove the oil stains on the surface of the bones as well as the leftover bone marrow, followed by soaking in $5 \%$ sodium hypochlorite $(\mathrm{NaClO})$ solution in sealed plastic containers. The bones were left in the laboratory for 10 days. The bones were then rinsed with running tap water to remove chemical residues followed by drying in sunlight for two days. After that, the specimens were stored in clean and dry storage boxes at room temperature (Enax et al., 2013).

\section{Assessment of Teeth and Skeletal Remains}

Tooth count was made by counting the teeth alveoli at the cranial and dentary parts of the skull for comparison between species. Dentition code for both species followed (Bezuijen, Hartoyo, Elliot \& Baker, 1997). The differences in features of the teeth were analysed, drawn and photographed. Assessment of skulls and other skeletal specimens followed standard protocol by Mueller-Töwe (2006). Photographs were captured for records.

\section{Arranging the Skeletal Remains}

The final stage of this project involved the arrangement of the skeletal remains of both animals, following a modified method from Mueller-Töwe (2006). The arranged skeletal remains were photographed and documented. In addition, the differences between the osteoderms of the animals were also analysed and photographed.

\section{RESULTS \& DISCUSSION}

\section{Assessment of Teeth}

\section{Dentition of $C$. porosus}

The teeth of $C$. porosus are conical, pointed, and unequal in size (Figure 1). The tooth crown shows a fine vertical striation on the surface of the teeth. The upper jaw number of alveoli varies from 4 to 5 in the premaxillae, 14 at the maxillae of each side, and 15 alveoli on each side of the dentary. Hence, the dentition code is: $\frac{p m(4-5)+m(14)}{d(15)}$ (Bezuijen et al., 1997). 


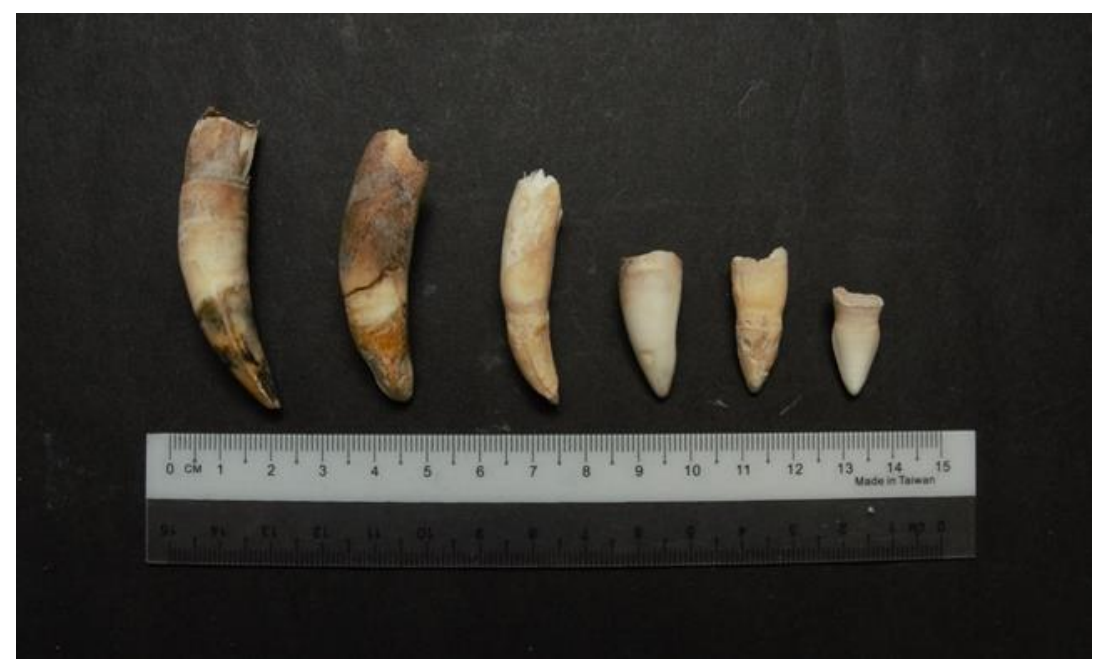

Figure 1. The teeth of $C$. porosus (lateral view).

The largest teeth of the upper jaw were identified at premaxillary 4, and maxillary 4 and 5. The largest teeth of the lower jaw were located at dentary 1, 4, and 11. Based on observation, the dentition was categorised as heterodont, since it possesses variable forms and functions of the teeth, at different parts of the tooth row (Hilderbrand,1995). Equally important, the teeth fell under the thecodont group because the teeth have their roots in their sockets and are continuously replaced (Figure 2). According to Hilderbrand (1995), the development of the replacement tooth already took place even before the first tooth is fully functional.

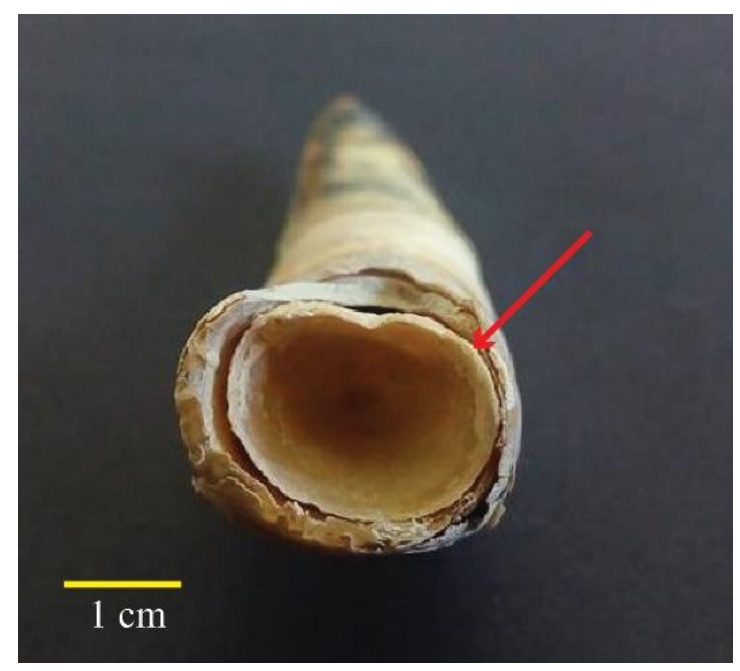

Figure 2. Replacement teeth of C. porosus (dorsal view).

In relation to that, the teeth at the upper and lower jaws alternate with each other, and each tooth possessed its own space even when the mouth is shut. For instance, the $4^{\text {th }}$ dentary tooth is able to fit into a lateral groove that is situated in between the premaxillae and maxillae. Majority of the big teeth are protruding outward to fit into their own lateral groove and this explains the reason why the teeth of a $C$. porosus are visible when the mouth is closed.

\section{Dentition of T. schlegelii}

T. schlegelii possessed curvy, conical, and sharp pointed teeth, that vary slightly in size (Figure 3 ). The surface of the tooth crown also shows a fine vertical striation. The upper jaw number of alveoli varies from 5 in the premaxillae, 14 to 15 at the maxillae of each side, and 20 alveoli on each side of the dentary. Hence, the dentition code is: $\frac{p m(5)+m(14-15)}{d(20)}$ (Bezuijen et al.,1997). 


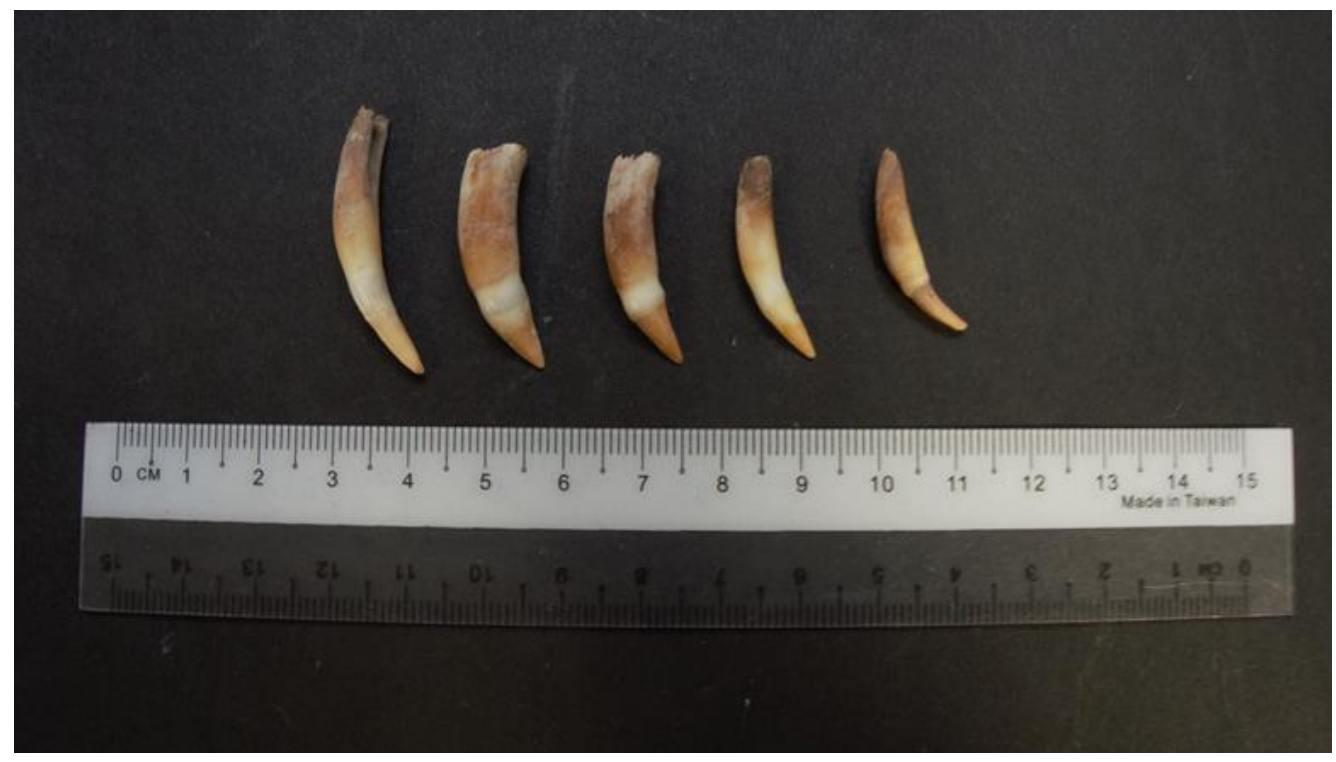

Figure 3. The teeth of T. schlegelii (lateral view).

The largest teeth of the upper jaw were identified at premaxillary 2 and 3, and at maxillary 5 . The largest teeth of the lower jaw were located at dentary 1 and 3. The dentition can be classified as almost homodont, because almost no difference could be observed in terms of the shape and function of the teeth (Hilderbrand, 1995). In addition, the teeth also fell under the thecodont group, because each tooth possesses its own socket and the teeth are continuously replaced (Figure 4).

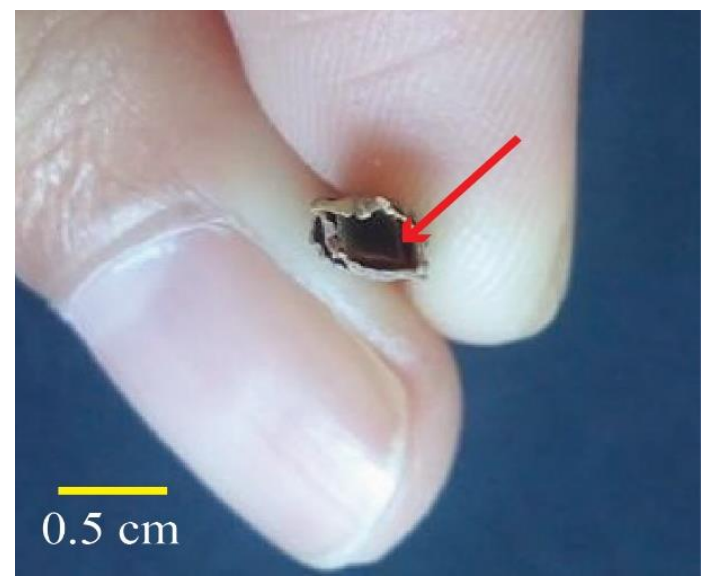

Figure 4. The replacement teeth of T. schlegelii (apical view).

Since the teeth size are slightly variable and almost approaching a homodont dentition, the jawline is straight rather than undulating. All the teeth of the upper and lower jaw alternate with each other, and each one of them possessed its own "tooth notch". For example, the first tooth of the upper jaw started at the middle part of the maxillae, while for the first tooth of the dentary started at the edge sides of the dentary. Thus, the upper and lower first teeth alternate at occlusion (Grigg \& Gans, 1993).

\section{Arrangement of Skeletal Remains}

The cervical vertebrae (the bones that support the neck) are bones situated immediately after the skull, followed by the thoracic vertebrae, which characterized by the possession of ribs. Then there are lumbar, sacral and caudal vertebrae. Caudal vertebrae (tail bones) are located after sacral vertebrae and some of the caudal bones carry chevron bones at the ventral side (Liem, Bemis, Walker \& Grande, 2001). In this study, it is noted that the vertebral column of both animals shared the same morphological features. However, the number of cervical, thoracic, sacral and caudal vertebrae are different as some of the vertebral columns may have been completely decomposed, thus were unable to be located at the sampling site. In this study, the total number of vertebrae for C. porosus is 46 vertebrae (Figure 5), while only 40 vertebrae were present in T. schlegelii (Figure 6). 


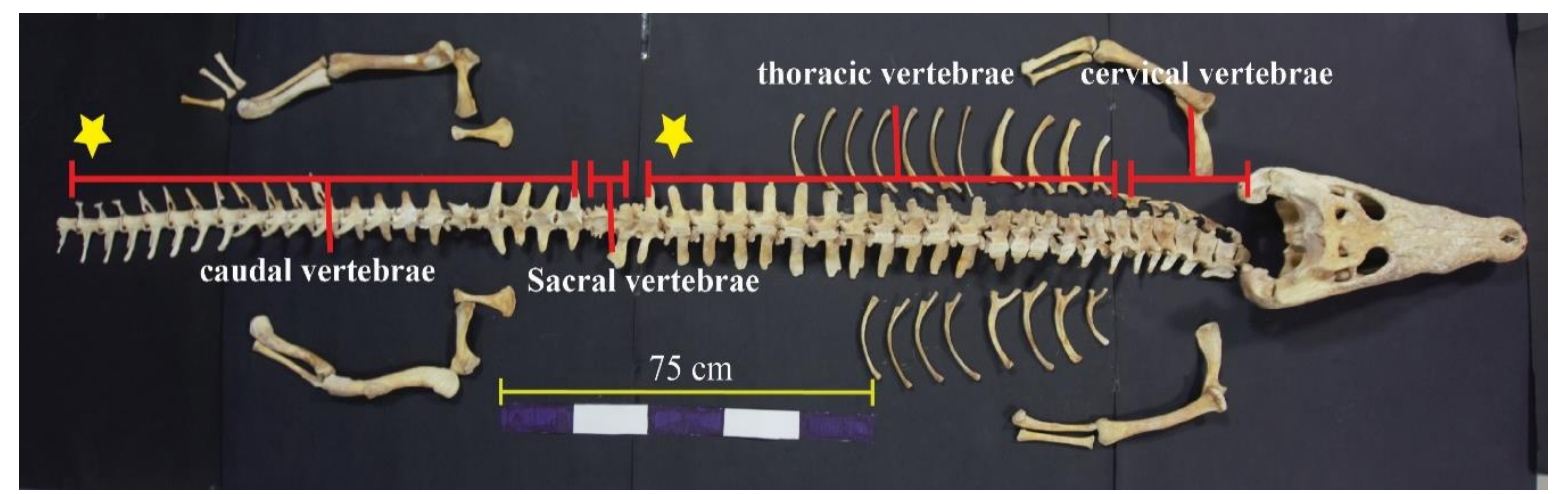

Figure 5. Vertebral column of skeletal remains of $C$. porosus (dorsal view). Stars indicate possible missing vertebrae. This study found: cervical vertebrae $=6$, thoracic vertebrae $=15$, sacral vertebrae $=2$, caudal vertebrae $=21$.

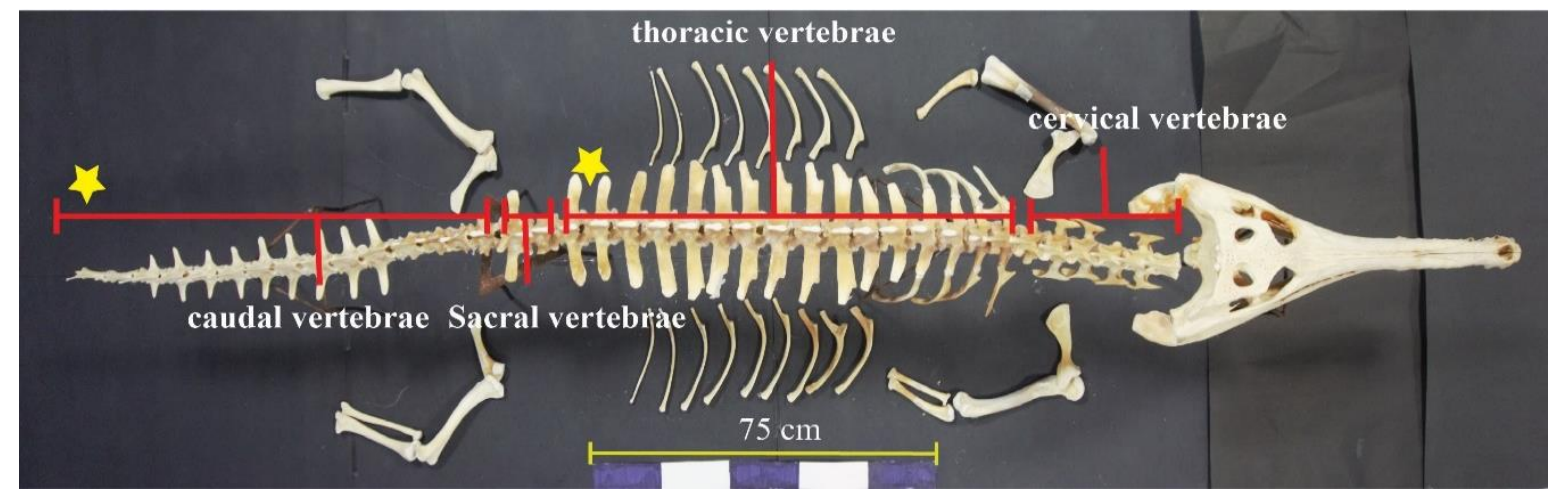

Figure 6. Vertebral column of skeletal remains of $T$. schlegelii (dorsal view). Stars indicate possible missing thoracic and caudal vertebrae. This study found: cervical vertebrae $=6$, thoracic vertebrae $=19$, sacral vertebrae $=2$, caudal vertebrae $=13$.

\section{Differences Between the Crania}

In this study, there are approximately eight differences in morphology between both species (Figure 7-14). However, findings reported here must be read with caution, as examinations were only done on a limited number of samples and did not take into account different phases of growth (hatchling, yearling, subadult and adult). Upon deceased, measurement records kept by Matang Wildlife Center noted that both were males, with total length of approximately $2.2 \mathrm{~m}($ C. porosus) and 2.4. $\mathrm{m}$ (T. schlegelii).

The snout of $C$. porosus premaxillae is broaden in posteriodorsal manner and narrowing down the size as it approaches maxillae. Thus, one could observe differences between premaxillae and maxillae (Figure 7a). On the other hand, premaxillae of $T$. schlegelii is widen anteriorly at about the size of a spoon, and there is no obvious difference between the fusion of premaxillae and maxillae (Figure 7b). The external nares of C. porosus (length: $3.2 \mathrm{~cm}$, width: $2.8 \mathrm{~cm}$ ) (Figure 7a) are larger compared to those of T. schlegelii (length: $2.1 \mathrm{~cm}$, width: $2.5 \mathrm{~cm}$ ) (Figure 7b). In addition, the nasal pathway of $C$. porosus is wider and its wall is separated from the maxillae (Figure 7a), compared to T. schlegelii who possessed a narrow nasal pathway.

In contrast to the flat and smooth surface of maxillae of $T$. schlegelii, cranium of $C$. porosus has formation of bulge or swollen over the alveolus of the fifth maxillary tooth, the bony socket for the root of the tooth (Figure 8a and 8 b). For $C$. porosus, the protruding bones of the quadratojugal is located at the inferior temporal fossa; it is a blunt pointed and shorter in size (approximately $1.0 \mathrm{~cm}$ ) (Figure 9a), while the protruding bones of quadratojugal of $T$. schlegelii is a sharp-pointed and longer in size (approximately $1.7 \mathrm{~cm}$ ) (Figure 9b).

Close to the inferior temporal fossa is the eye socket of $C$. porosus (Figure 10a). The eye socket of $C$. porosus is circular in shape, while the eye socket of T. schlegelii is in the shape of a capital d (D) (Figure 10b). Besides, for C. porosus, the surface of the skull has a rough texture and possesses patterns of irregular size and shape of the pits (Figure 11a). The parietal, squamosal, frontal, prefrontal, jugal and the postorbital of saltwater crocodile are the bones that developed more formation of pits compared to other parts of the cranium. Whereas, the skull of $T$. 
schlegelii has a smooth surface (Figure 11b). Additionally, its cranial platform is almost flattened and has the shape of a trapezoid. In relation to that, the parietal, frontal, prefrontal, squamosal, jugal, postorbital of the skull shows patterns of pits on the external dorsal surface. The shape of pits is unequal in size, some with circular pattern, and some with elliptical patterns, and they developed differently on the respective bones. Next, another important character observed is the supraoccipital, which is located below the parietal. The edge of a supraoccipital of $C$. porosus is parallel to the edge of the parietal and hidden beneath the parietal of the cranium (Figure 12a). Whereas, the supraoccipital of $T$. schlegelii has structure that protrude from beneath the parietal and can be distinguished from dorsal view (Figure 12b).

Another character of the skull that shows variation is located at the ventral part of the cranium, which is the suborbital fenestrae, referring to the pair of holes located beneath the eye socket. For C. porosus, suborbital fenestrae possess elongated longitudinal elliptical shape (Figure 13a), while T. schlegelii has the shape of an elongated triangle (Figure 13b). Additionally, located close to suborbital fenestrae is the pterygoid. Pterygoid of C. porosus has a larger surface area compared to pterygoid of T. schlegelii. Lastly, the internal nares of C. porosus have the shape of an infinity symbol, $\infty$ (Figure 14a), while for T. schlegelii, the internal nares show circular shape (Figure 14b).
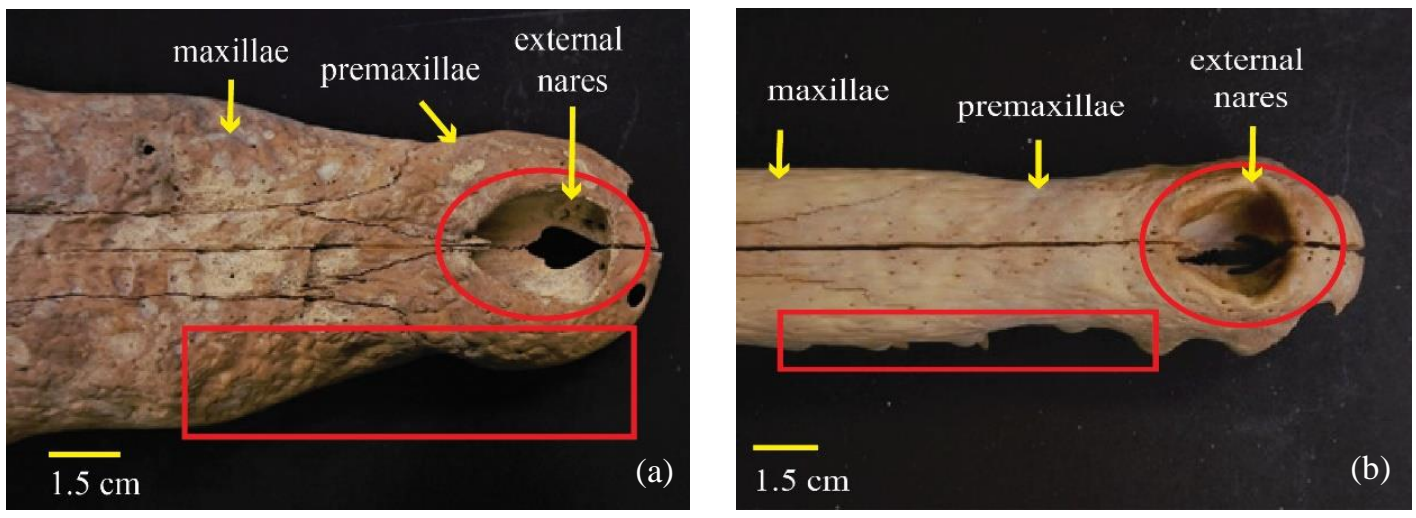

Figure 7. Snout of C. porosus (a) and T. schlegelii (b).
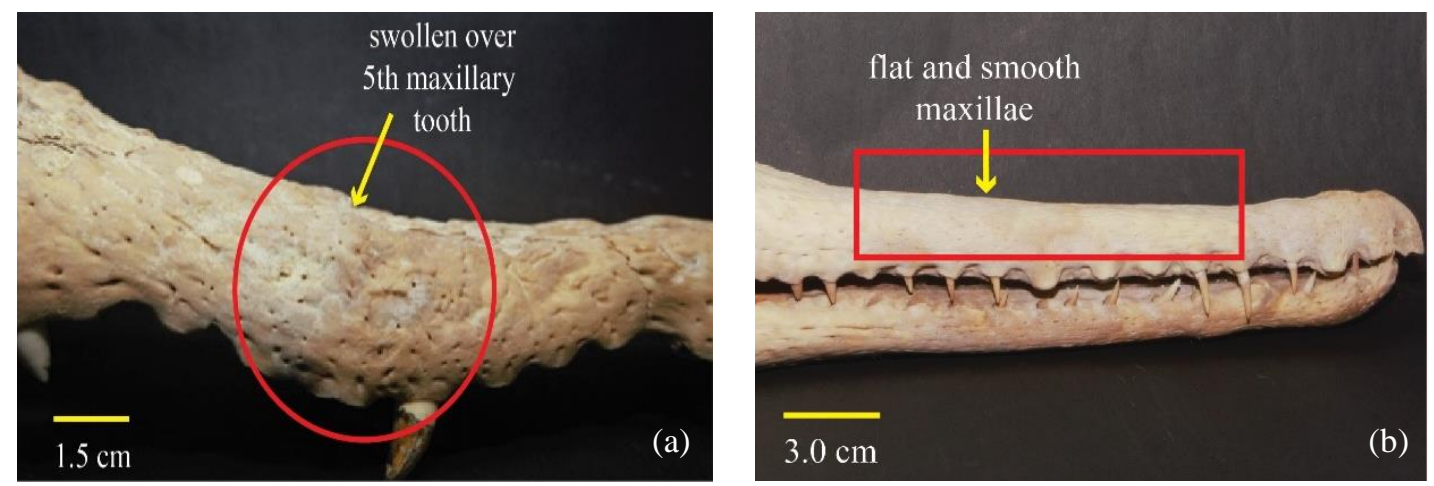

Figure 8. Maxillae of C. porosus (a) and T. schlegelii (b).
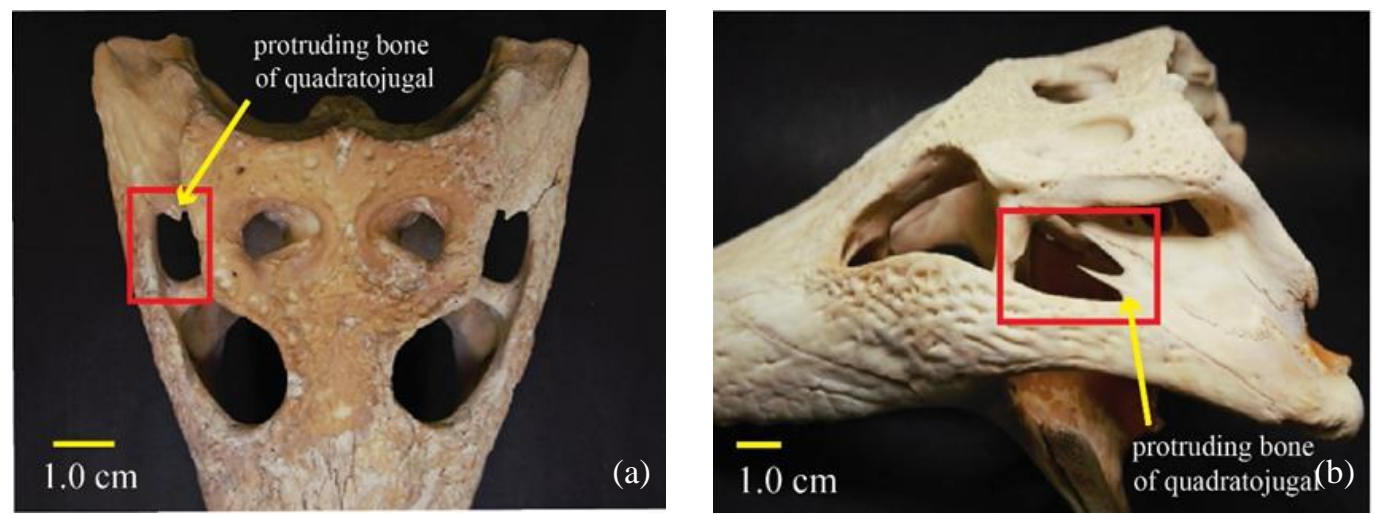

Figure 9. Protruding bones of quadratojugal of C. porosus (a) and T. schlegelii (b). 

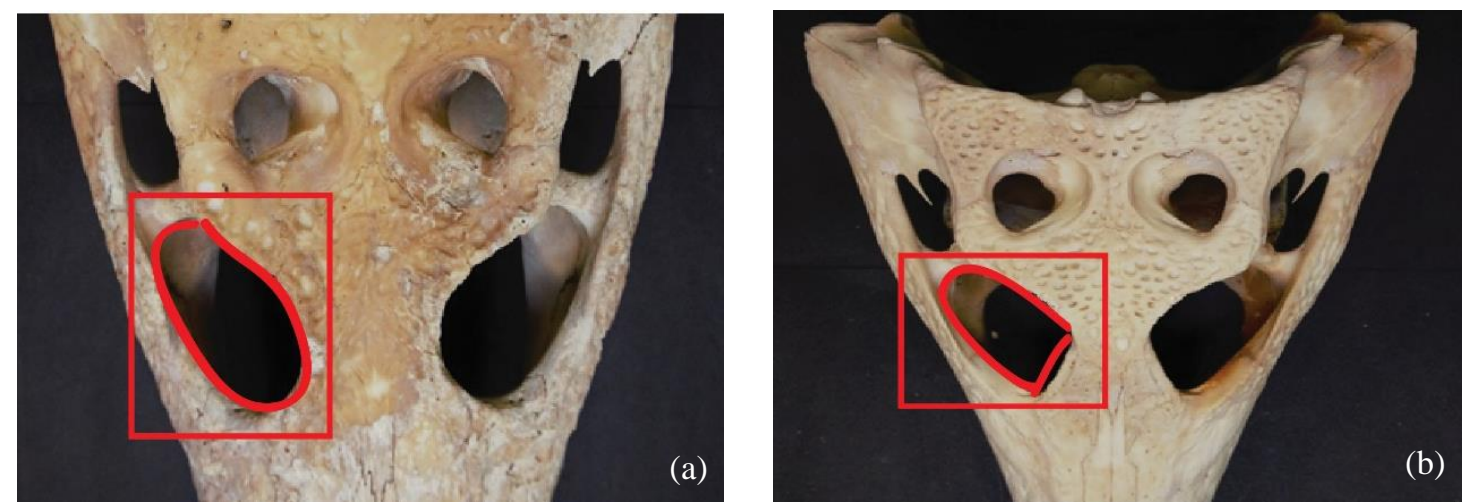

Figure 10. Eye socket of C. porosus (a) and T. schlegelii (b).
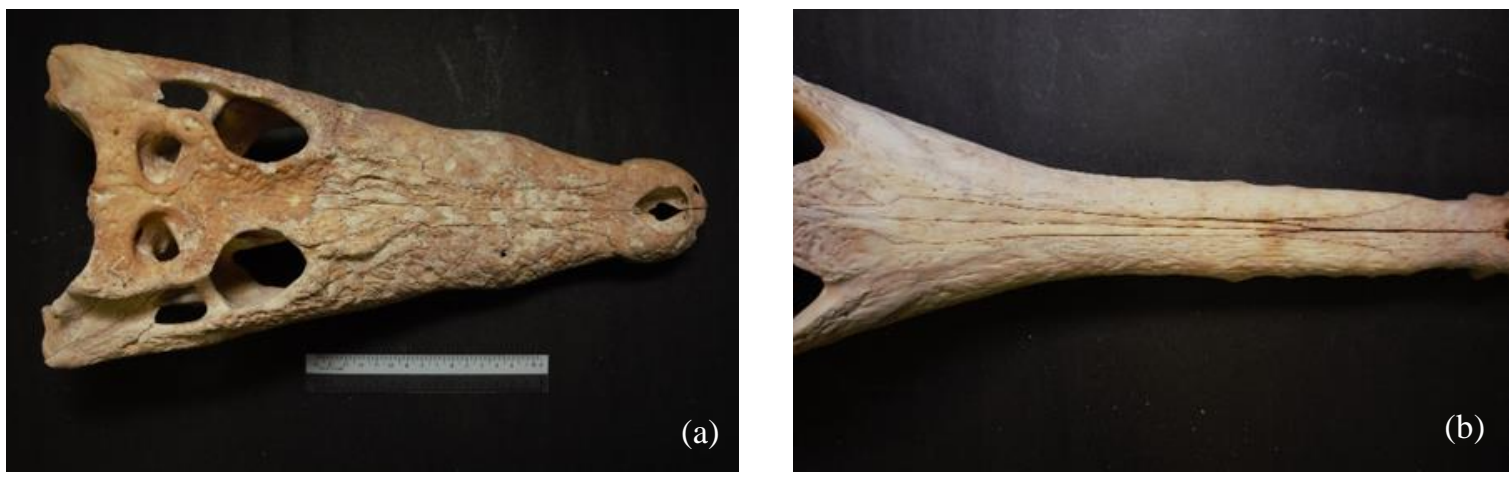

Figure 11. C. porosus's rough skull surface (a) and T. schlegelii's smooth skull surface (b).
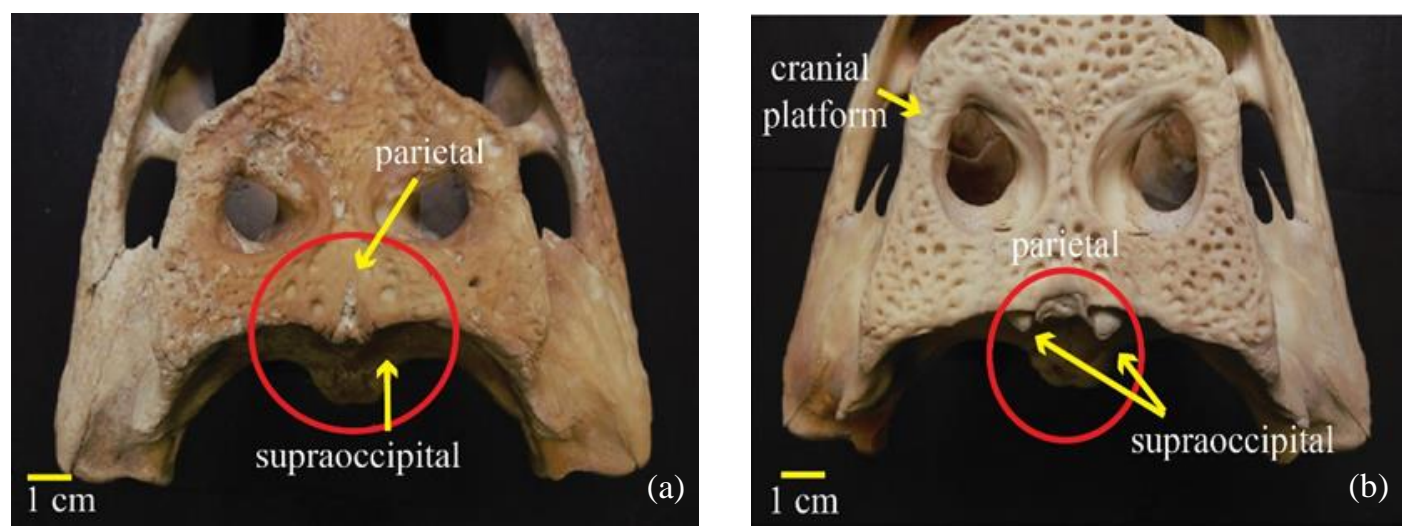

Figure 12. Supraoccipital of $C$. porosus is hidden beneath the parietal (a) while Supraoccipital of T. schlegelii is visible from parietal (b).
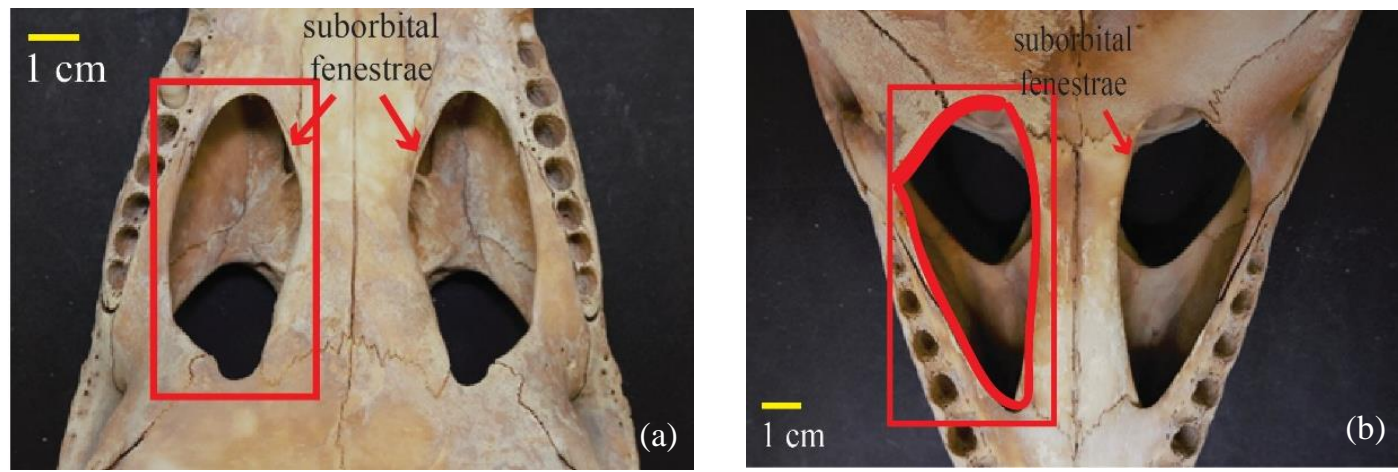

Figure 13. Suborbital fenestrae of C. porosus (a) and T. schlegelii (b). 

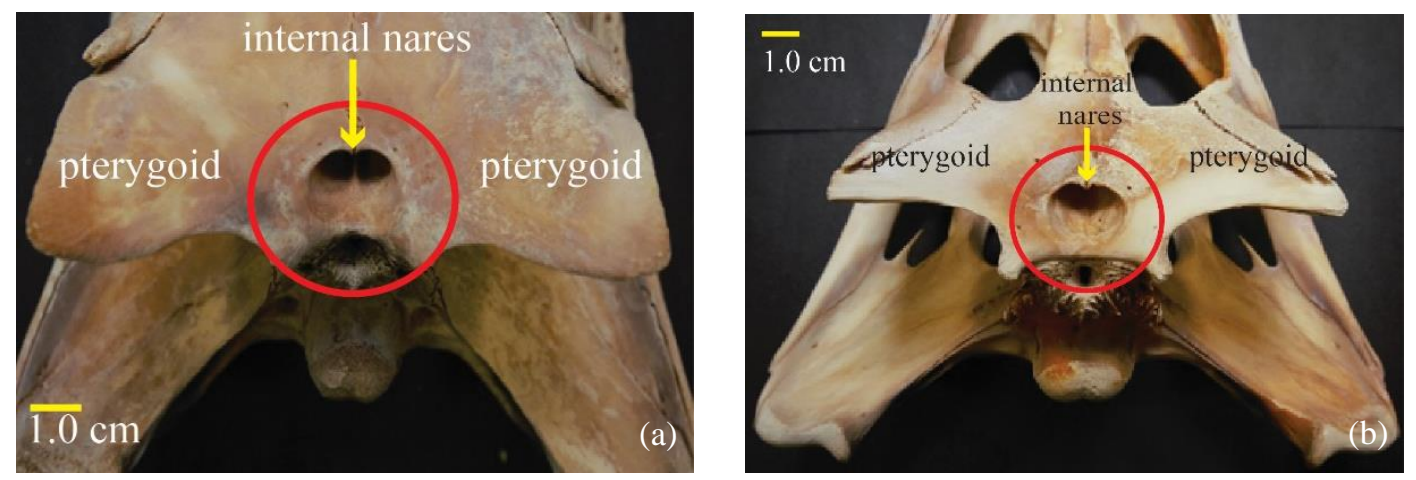

Figure 14. Internal nares of C. porosus (a) and T. schlegelii (b).

\section{Morphology of the Osteoderms}

Osteoderms are defined as plate of bones, placed under the horny scutes of crocodilians and they are assumed to be derived from dermal scales (Hilderbrand, 1995). In this study, two types of osteoderms were obtained (Figure 15). In general, osteoderms of T. schlegelii are square in shape and have relatively larger in size. T. schlegelii also has circular osteoderms which are relatively smaller in size. In C. porosus, all of the osteoderms have circular and elliptical shapes, and are smaller in size compare to those belonging to $T$. schlegelii. Despite these, both animals show similarities in terms of possession of irregular size of pits on the surface of the osteoderms. T. schlegelii has osteoderms that are ornamented with large circular pits, while for $C$. porosus, the osteoderms pits formation looks like dots and irregular indentations on the surface. Other than that, osteoderms of both species have horny ridges. However, it is also noted that not all osteoderms of $T$. schlegelii have the horny ridges, most probably depending on their locations on the body of the animal.
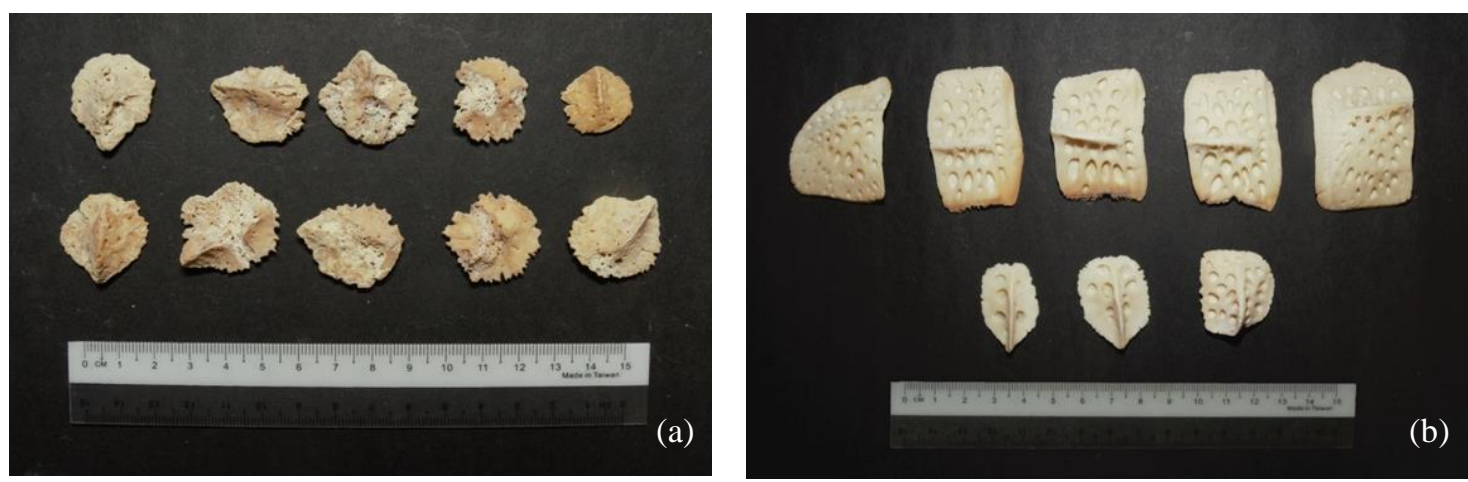

Figure 15. Dorsal view of osteoderms of C. porosus (a) and T. schlegelii (b).

\section{Exhibition of Skulls, Skeletal Remains, Teeth and Osteoderms}

The materials obtained in this study have been displayed in Science Exhibitions in several schools around Kuching, Sarawak. The exhibitions allow participants to have hands on experience touching the skulls, bones and teeth as well as arranging the skeletal remains, hoping to instil interest among young people in nature and science. This is in line with suggestion by Hastings and Dooley (2017), who reported that giving opportunity to people to participate in excavations and fossil collecting exercises will help to contribute to new discoveries and elevated interest in forensic science and palaeontological studies.

\section{CONCLUSION}

This study has documented characters that are useful to differentiate between $C$. porosus and $T$. schlegelii in terms of dentitions, skeletal remains and osteoderms. Specimens gathered during this study are useful for future wildlife forensic study as well as to spark some interests for budding palaeontologists in Sarawak. However, certain parts (bones) are missing, thus future work is needed to complete the whole bone structures of both species. 


\section{ACKNOWLEGEMENT}

Authors would like to thank Ministry of Higher Education of Malaysia for funding the project FRGS/STWN 10(01)/1066/2013 (12) and UNIMAS for land transportation, laboratories equipment, chemicals and consumables. Thank you to staffs of Sarawak Forestry Corporation (Matang Wildlife Centre) for technical advice. Thank you to Forestry Department, Sarawak for granting permits to conduct research on biological resources (Permit No. NCCD.907.4.4.4 (jld.10)-255 and Park Permit No. 263/2014).

\section{REFERENCES}

Bezuijen, M. R., Shwedick, B., Simpson, B. K., \& Stuebing, R. B. (2014). Tomistoma schlegelii. The IUCN Red List of Threaten Species Version 2014.3. Retrieved June 10, 2017, from www.iucnredlist.org.

Bezuijen, M. R., Shwedick, B. M., Sommerlad, R., Stevenson, C., \& Stuebing, R. B. (2010). Status survey and conservation action plan. Darwin: Wildlife Management Pty Limited.

Bezuijen, M. R., Hartoyo, P., Elliot, M., \& Baker, B. A. (1997). Project Tomistoma. Second report of the ecology of the false gharial (Tomistoma schlegelii) in Sumatera. Darwin: Wildlife Management International Pty Limited.

Bezuijen, M. R., Cannucciari, P., Ramono, W. S., \& Webb, G. J. W. (1995). Project Tomistoma. Field trip to Palembang, Sumatera Selatan, Indonesia. 14 March - 3 April: Trip Report. Wildlife Management International Pty Limited.

Britton, A. (2012). Current distribution of Crocodylus porosus. Retrieved July 10, 2017, from www.crocodilian.com.

Cox, J. H., \& Gombek, F. (1985). A preliminary survey of the crocodile resource in Sarawak East Malaysia," IUCN/WWF Project MAL 74/85, World Wildlife Fund Malaysia \& the National Parks and Wildlife Office, Forest Department, Sarawak, Malaysia.

Enax, J., Fabritius, H., Rack, A., Prymak, O., Raabe, D., \& Epple, M. (2013). Characterization of crocodile teeth: Correlation of composition, microstructure and hardness. Journal of Structural Biology, 184, 155-163.

Ferraro, J. V., \& Binetti, K. M. (2014). American alligator proximal pedal phalanges resemble human finger bones: Diagnostic criteria for forensic investigators. Forensic Science International, 240, 151.e1-151.e7.

Gani, M. I. Z.A. (2014). Population Density, Human-Crocodile Conflict and Genetic Variations among Saltwater Crocodile, Crocodylus porosus in Sarawak (master's thesis). Universiti Malaysia Sarawak, Sarawak, Malaysia.

Gani, M. I. Z. A., \& Hassan, R. (2013). Crocodiles of Sungai Sibu Laut. In L. Nyanti, N. Ismail, R. Hassan, S. Mohamad \& S. A. K. A. Rahim (Eds.), Aquatic Science Colloquium 2012 Monograph (pp. 13-18).

Grigg, G., \& Gans, C. (1993). Fauna of Australia Vol 2A Amphibia and Reptilia. Canberra, Australia: Australian Government Publishing Service.

Gunther, A. C. (1861). Reptiles of British India (pp. 61-63). Janpath, New Delhi: Oxford Publication.

Hassan, R., Md Adzhar, M. A. A., Gani, M. I. Z. A., \& Ahmad, R. (2018) Assessment of wild saltwater crocodile population in Bako River, Western Sarawak, Malaysian Borneo for potential ecotourism industry. Malaysian Applied Biology, 47(1), 131-138.

Hassan, R., Ahmad, R., Adzhar, M. A. A., Gani, M. I. Z. A., Ayob, A., \& Zainuddin., R. (2016). Notes on the wild Tomistoma populations in western Sarawak, Malaysian Borneo. International Journal of Ecology. Article ID 4357623, 7 pages. http://dx.doi.org/10.1155/2016/4357623

Hassan, R., \& Gani, M. I. Z. A. (2013). Crocodiles in western of Sarawak, Malaysia. Proceedings of the 22nd Working Meeting of the IUCN SSC Crocodile Specialist Group, World Crocodile Conference (pp. 90-95). Negombo, Sri Lanka.

Hastings, A. K., \& Dooley, A. C. (2017). Fossil-collecting from the middle Miocene Carmel Church Quarry marine ecosystem in Caroline County, Virginia. Field Guides, 47, 77-88.

Hilderbrand, M. (1995). Analysis of vertebrate structure ( $4^{\text {th }}$ ed.). New York, NY: John Wiley \& Sons Inc.

Liem, K. F., Bemis, W. E., Walker, W. F., \& Grande, L. (2001). Functional anatomy of the vertebrates $\left(3^{\text {rd }}\right.$ ed.). Belmont, CA: Brooks/Cole-Thomson Learning.

Md Adzhar, M. A. A., \& Hassan, R. (2017). Relationships among Tomistoma schlegelii in Malaysia Based on Cyt b-Control Region Gene Analysis. International Journal of Zoology, 2017. Article ID 5431041, 6 pages. https://doi.org/10.1155/2017/5431041

Mueller-Töwe, I. J. (2006). Anatomy, phylogeny, and palaeoecology of the basal Thalattosuchians (Mesoeucrocodylia) from the Liassic of Central Europe (Doctor of Philosophy thesis). Gutenberg University of Mainz, Mainz, Germany.

Pine, A. (2013). Tomistoma, False Gharial, Sunda Gavial (Tomistoma schlegelii). A Report for Mohamed bin Zayed Species Conservation Fund, project number 12255301. Retrieved June 10, 2017, from http://www.speciesconservation.org/case-studies-projects/tomistoma-false-gharial sunda.

Ritchie, J., \& Jong, J. (2002). Man Eating Crocodiles of Borneo. Kota Kinabalu, Sabah: Natural History Publications (Borneo). 
Shaker, N. A., \& El-Bably, S. H. (2015). Morphological and Radiological Studies on the Skull of The Nile Crocodile (Crocodylus niloticus). International Journal of Anatomy and Research, 3(3), 133-140.

Stuebing, R. B., Bezuijen, M. R., Auliya, M., \& Voris, H. K. (2006). The current and historic distribution of Tomistoma schlegelii (the False Gharial) (Müller, 1838) (Crocodylia, Reptilia). The Raffles Bulletin of Zoology, 54(1), 181-197.

Stuebing, R. B., Sah, S. A. M., Lading, E., \& Jong, J. (2003). The status of Tomistoma schlegelii (Mueller) in Malaysia. Proceedings of the 17th Working Meeting of the IUCN-SSC Crocodile Specialist Group (pp. 136140). IUCN: Gland, Switzerland.

Webb, G. J. W., Manolis, S. C., \& Brien, M. L. (2010). Saltwater Crocodile, Crocodylus porosus. In S. C. Manolis \& C. Stevenson (Eds.), Crocodiles: Status Survey and Conservation Action Plan ( ${ }^{\text {rd }}$ ed.) (pp. 99-113). Crocodile Specialist Group: Darwin.

Willis, R. E., McAliley, L. R., Neely, E. D., \& Densmore, L. D. (2007). Evidence for placing the false gharial (Tomistoma schlegelii) into the family Gavialidae: inferences from nuclear gene sequences. Molecular Phylogenetics and Evolution, 43(3), 787-794.

Zaini, M. K., Ripot, S., Ubang, C. K., Francis, R., \& Simon, A. M. (2014). Crocodile Survey at Kuching, Samarahan and Sri Aman Division, Sarawak, Malaysia. Borneo Crocodile Forum, Sarawak Malaysia. 